\title{
The Moderating Effect of Environmental Turbulence on the Strategic Agility-Performance Relationship: Empirical Evidence from Lagos State, Nigeria
}

\author{
M. A. Arokodare, Ph.D ${ }^{1}$ \\ ${ }^{1}$ M. A. Arokodare, Babcock University, Illishan, Ogun State, Nigeria \\ Correspondence: M. A. Arokodare, Ph.D, Babcock University, Illishan, Ogun State, Nigeria. Dr. M. A. Arokodare is \\ currently the Chairman of First Ally Asset Management Company Limited and CEO of M \&G Portfolio Limited and \\ was formerly Group Executive Director/CFO of Nigerian National Petroleum Corporation. E-mail: \\ biodunarokodare@yahoo.com
}

Received: October 5, 2020

Accepted: November 10, $2020 \quad$ Online Published: January 2, 2021

doi:10.5430/bmr.v10n1p1

URL: https://doi.org/10.5430/bmr.v10n1p1

\begin{abstract}
Scholars in strategic management argued that strategic agility measures do enhance firm performance and mitigate environmental turbulence risks. This study therefore examined the moderating effect of environmental turbulence on the relationship between strategic agility and performance of oil and gas marketing companies in Lagos State, Nigeria. Population of the study was 515 managers of major oil and gas marketing companies in Lagos State. Cross-sectional survey research design was adopted with total enumeration. The research instrument was found reliable and valid with Cronbach's alpha and KMO greater than 0.7 and 0.5 respectively. The data was analyzed using descriptive statistics, Pearson correlation, and multiple and hierarchical regression methods of analyses. Findings revealed that among oil and gas marketing companies in Lagos State, Nigeria, there was positive and significant relationship between strategic agility and performance; strategic agility had positive and significant effect on performance while environmental turbulence significantly moderated the relationship between strategic agility and performance. The study concluded that strategic agility affected and related with firm performance and also environmental turbulence moderated the relationship between strategic agility and performance of oil and gas marketing companies in Lagos State, Nigeria. Therefore, it is recommended that oil and gas marketing companies in Nigeria should fully and dynamically embrace strategic agility practices and continuously develop their capabilities for proper and timely sensing of and responding to changes in their business environment in order to improve their performance over their competitors. Limitations of the study and areas for future research were highlighted.
\end{abstract}

Keywords: Dynamic capabilities, environmental turbulence, firm performance, strategic agility, oil and gas marketing companies

\section{Introduction}

Threats and opportunities arising from environmental turbulence have been established to impact on business performance (Kim, 2018; Kwon, Ryu, \& Park, 2018). In mitigating environmental turbulence risks, oil and gas marketing companies across the globe have focused on strategic workforce agility in achieving targeted performance. Volatility risks in the oil and gas industry triggered by environmental turbulence serves as a threat in achieving targeted performance. Therefore, oil and gas companies cannot survive without significant consideration given to strategic agility measures in and impact of environmental turbulence on their business and operation routines as well as decision making processes. Oil and gas industry operators also need to maintain a high level of responsiveness to achieve agility and to remain competitive in the global marketplace especially after instability of oil prices and global financial crisis (Garbie, 2011). Considering the challenges created by business environmental turbulence in relation to firm performance, scholars around the globe have acknowledged the importance of strategic agility initiatives as a proactive business process in curtailing environmental turbulence so as to enhance firm performance especially in the oil and gas industry (Arokodare \& Asikhia, 2020a).

A growing number of organizations are recognizing the impact of environmental threats and pressures on their activities and operations. One of the main issues in this process is coping with uncertainty created by environmental 
turbulence. In today's 21 st century market conditions, oil and gas companies are faced with variability of dynamic changes that frequently occur both concurrently and unpredictably and which forces oil and gas companies to revise their work practices and methods continuously in order to adapt quickly (Anggraini \& Sudhartio, 2019). In this context, strategic agility is known as the ability of an organization to manage market change through rapid proactive responses to threats and market opportunities in order to achieve targeted firm performance. In Nigeria, Ehie and Muogboh (2016) observed that the turbulence of the business environment is usually accentuated by issues pertaining to political instability, sectoral terrorism, economic and financial uncertainties, and high levels of unemployment leading to poverty and insecurity. Ojo and Ajayi (2017) also identified ineffective leadership, poor implementation of development plans, unfair competition, institutional void, lack of sound regulations and poor infrastructure as some of the factors responsible for the turbulence of the business environment. These were echoed by Ogah (2018) in his study of productivity and employee behavior change strategies in two Nigerian manufacturing organizations. Therefore, in a turbulent environment, one of the important features of organization's key success factors is strategic agility.

Specifically, the companies in the oil and gas industry were beleaguered with the problems of environmental turbulence via price volatility, unstable regulatory policies and infrastructural deficiency which hindered achievement of their targeted performance. According to Kim (2018), most oil and gas companies in developed economies proactively react to environmental turbulence through workforce agility in order to achieve firm performance unlike those in developing economies that reluctantly respond to the challenges posed by dynamic environmental turbulence.

In literature on strategic agility within and outside Nigeria contexts, scholars in strategic management argued that strategic agility measures enhanced firm performance and mitigated environmental turbulence risks (Abbas \& Hassan, 2017; Claub, Abebe, Tangpong, \& Hock, 2019; Oyerinde, Olatunji, \& Adewale, 2018). However, Arokodare and Asikhia (2020b) pointed out that most of the business firms especially organisations in the oil and gas industry in Nigeria have recorded unstable performance due to inappropriate employment of strategic agility measures as well as slow strategic response to challenges of environmental turbulence such as uncertainty, globalization, innovation, creativity, and changing customers' preferences.

Oil and gas marketing companies in developing economies like Nigeria have found it increasingly difficult and challenging in achieving targeted firm performance due to turbulent business environment and unstable policies characterized by poor strategic agility measures towards shifting economic policies, organizational culture rigidity, regulatory uncertainty and infrastructural deficit (PWC, 2018). Anggraini and Sudhartio (2019) emphasized that most organisations are not sure how to deal with turbulent environments, thus adversely affecting firm performance. Specifically, Oyerinde, Olatunji, and Adewale (2018) and Arokodare and Asikhia (2020) stated that strategic agility measures misplacement towards environmental turbulence and this led to adverse effect on the performance of oil and gas companies in Nigeria. Considering the identified problems, this study aimed to investigate:

1) The relationship between strategic agility and firm performance

2) The effect of strategic agility on firm performance

3) The moderating effect of environmental turbulence on the relationship between strategic agility and firm performance.

The rest of this article is structured as follows. Section 2 reviews existing literature on the study variables, and develops the theoretical framework and the hypotheses. Section 3 describes the methodology adopted for the study. Section 4 reports the main results and discusses the findings. Section 5 presents the article's conclusions and outlines some recommendations for management. The last section highlights the limitations of the study and suggestions for future research.

\section{Literature Review}

This sub-section of this study focused on conceptual definitions of the variables, empirical literature review and theoretical framework.

\subsection{Environmental Turbulence}

Oginni and Adesanya (2013) averred that organisations face an increasingly dynamic, complex, and unpredictable environment, where technology, globalisation, resource shortages, wide swings in the business cycle, changing social values, competitors, customers, suppliers, and a multitude of other dynamic forces impact on overall performance of these organisations. Environmental turbulence, according to Anggraini and Sudhartio (2019), is defined as environmental conditions with high level of uncertainty and risk. Environmental turbulence is an important construct that captures volatility in the corporate environment. It is made up of a competitive business environment and risks that come up from the company, and the complexity and heterogeneity of the supply chain within and outside the domain of 
the industry (Rimita, 2019). Nnamani and Ajagu (2014) referred to environmental turbulence as the major factors and forces outside the organisation that have the potential to significantly affect the performance of the organisation. These factors that happen outside the business are known as external factors or influences which determine the direction of an organisation towards its goals and objectives. These external factors affect the main internal functions of the business and possibly the objectives of the business and its strategies (Gathenya, 2012). Boyne and Meier (2009) and Ibidunni and Ogundele (2013) conceptually stated that environmental turbulence is one element of general models of the task environment that constrains organizational behavior and performance; it is the unpredictable change in munificence and complexity of an organization's environment. Pavlou and Sawy (2011) stated that environmental turbulence is also characterized by uncertainties arising from unexpected changes in market demand, consumer preferences, new technological developments, and technological breakthroughs. They found that in a turbulent environment, there are three types of capabilities that will produce strategic advantage such as: operational (the ability to carry out processes); dynamic (planned capabilities to reconfigure operational capabilities); and improvisational (the learned ability to spontaneously reconfigure operational capabilities). The last two abilities can be seen as dynamic capabilities in general. Therefore, there is a relationship between dynamic capability and competitive advantage in a turbulent environment (Banerjee, Farooq, \& Upadhyaya, 2018).

In sum, Anggraini and Sudhartio (2019) asserted that environmental turbulence is unpredictable change in the munificence and complexity of an organizational business environment because the extent of change is unexpected as well as the larger the unpredictable change, the bigger the negative impact on organizational business process and performance.

In literature, the negative effect of environmental turbulence on firm performance has been empirically demonstrated in Lin and Germain (2003), Power and Reid (2005), and Turulja and Bajgoric (2019).

\subsection{Strategic Agility}

Doz and Kosonen (2008) defined strategic agility as organization's ability to ensure itself to be flexible to adapt in any environmental condition. They further conceptualised strategic agility as organization's ability to continually adjust their strategic direction and develop innovative ways to create value. The idea of renewal and adaptation can be conceptualized in strategic agility through the ability to connect insights about the external business environment with internal capabilities and convert same into actions so as to wade through environmental challenges. Strategic agility has been viewed by Tabe-Khoshnood and Nematizadeh (2017) as a concept consisting of two components: responsiveness and knowledge management. They further interpreted strategic agility as the ability of an organisation to detect changes through the opportunities and threats existing in the business environment, and to give rapid response through the recombination of resources, processes and strategies. Arokodare (2020) defined strategic agility as "the ability of the organisation to sense changes in dynamic, fast-paced environments, and to quickly respond to these changes by seizing market opportunities and maintaining competitiveness through building, combining, enhancing, mobilising and reconfiguring its capabilities and in the process attaining and sustaining superior performance beyond its competition" (p. 45). This definition amplifies the conceptualization of strategic agility and its dimensions by Mavengere (2013) and Anggraini and Sudhartio (2019).

Anggraini and Sudhartio (2019) stated that strategic agility consists of three capabilities: strategic sensitivity, collective commitment, and resource fluidity, all three of which must support each other to achieve success. According to Anggraini and Sudhartio (2019), strategic sensitivity includes the focus of the organization's attention and the level of intensity in which the company perceives and interprets the reality of market conditions, collective commitment is how company management can make quick and right decisions and without taking organizational politics into consideration, and resource fluidity is the ability of the firm to adjust and renew its business system and relocate resources quickly according to needs and circumstances. They argued that innovation and constant development of new capabilities are the only sources of excellence for sustainable competitiveness and to overcome environmental turbulence. Extensive review of the strategic agility literature shows that strategic agility has positive relationship with and significantly enhances firm performance and that it is a vital factor for organizational success and sustainability in the work environment, as well as the pursuit of excellence, work processes development, and ultimately achieving competitive advantage (Al-Romeedy, 2019; Kwon et al., 2018; Nzewi \& Moneme, 2016). It also indicates that strategically agile organisations can be successful in turbulent environments through the abilities of responsiveness, competence, flexibility and speed so that it achieves competitive advantage in the market (Arokodare, Asikhia, \& Makinde, 2019; Nafei, 2016; Oyedijo, 2012). Likewise, Tse, Zhang, Akhtar, and MacBryde (2016) revealed that firms that are more concerned about learning are more agile and are more responsive to environmental uncertainties. 


\subsection{Firm Performance}

The ability of an organization to meet its financial and non-financial targets is measured by the concept of firm performance (Arokodare \& Asikhia, 2020b). It is a set of financial and non-financial measures which offer information on the degree of achievement of objectives and results of the firm (Egbunike \& Okerekeoti, 2018; Lebans \& Euske, 2006). The concept of firm performance is fundamental to businesses as the key objective for business organisations is profit making (Olanipekun, Abioro, Akanni, Arulogun, \& Rabiu, 2015). Syafarudin (2016) defined firm performance as the outcome or accomplishment affected by the operations of the company in utilizing the resources owned. Jahanshahi, Rezaie, Nawaser, Ranjbar and Pitamber (2012) also described firm performance as a result of the actual outcome fashioned by a company which is measured and compared with the expected results. Musyoka (2016) portrayed firm performance as having improvement over time as a result of the shared values in the company while Jones and Charles (2010) viewed the concept with regards to set goals or objectives established by the management team and Davidsson (2004) considered regarded it as the strategic outcomes that organisations use to realise their goals, success or otherwise. Awino (2011) averred that for an organisation to be successful, it must have above average returns and identified performance drivers from the top to the lower levels of the organisation. In this study, firm performance was conceptualized in its multi-dimensional form and measured with the following indicators: market share, firm profitability, firm efficiency, competitive advantage, customer satisfaction, and firm creativity.

\subsection{Strategic Agility-Firm Performance Relationship}

Empirically, several studies on the concept of strategic agility and firm performance have established positive and significant link between the two concepts. For organisations to cope with dynamic competition and survive today's market globalisation, strategic agility is employed in the management style, process and decision making of the organisation all geared towards enhancing overall firm performance (Ashori, Veisari, \& Taghavi, 2015; Cegarra-Navarro, Soto-Acosta, \& Wensley, 2016; Qin \& Nembhard, 2015). Empirically and Al-Romeedy (2019) found that strategic agility has positive relationship with competitive advantage and significantly affects firm performance. The study revealed that strategic agility has become one of the important tools that help airlines survival, increasing competitiveness, and achieving excellence in a changing and volatile labor market, through delivery reliability, innovation, process flexibility, service quality and finally cost leadership. All these significantly affect overall firm performance. Likewise and Khorshid (2019) investigated the effects of organisational and strategic agility capabilities on university entrepreneurship and found that strategic agility capability had a direct, positive and significant effect on emotional and entrepreneurial ability and from the results of path analysis, strategic agility capability had a positive indirect effect on entrepreneurship through emotional ability with the eventual positive impact on firm performance. Kwon et al. (2018) in a case study of South Korean ventures that achieved growth by identifying opportunities continuously, found that strategic agility is a critical element of firm success with which entrepreneurs continuously identify, develop and capture new business opportunities. Hadad (2017) empirically upheld that having a strategic agility and thinking represents a competitive advantage to secure the future position and performance of an organisation in the market. Muthoni (2015) investigated the influence of strategic agility on competitive capability of private universities in Kenya while Okotoh (2015) conducted a study on the influence of strategic agility on operational performance of Trademark East Africa. Both Muthoni (2015) and Okotoh (2015) found that strategic agility has positive and significant effect on firm competitive capability and operational performance. On the other hand, various studies have shown that the reason for failure of some organisations is inattention to the changes in the dynamic environment and lack of suitable strategic agility and plans for these conditions which result in not providing the right product at the right time for the right customer, and thus creating problem of decline in organisational performance (Amin-Beidokhti \& Zargar, 2012; Zaridis \& Mousiolis, 2014). Specifically, Reid, and Zyglidopoulos (2004) observed that failure of understanding and anticipation, two key pillars of strategic agility, caused the failure and eventual collapse of multinational enterprises in China.

\subsection{Environmental Turbulence as a Moderator of Strategic Agility-Firm Performance Relationship}

Abbas and Hassan (2017) examined the moderating impact of environmental turbulence on relationship between business innovation and business performance. Their study found that technological turbulence significantly moderated the relationship between business innovation and business performance. Similarly, Pratono and Mahmood (2014) investigated the moderating effect of environmental turbulence in the relationship between entrepreneurial management and firm performance and found that environmental turbulence significantly moderated the relationship between entrepreneurial management and firm performance. They observed that through the challenges and opportunities provided by environmental turbulence, especially in form of new technology and new market direction, its moderating effect determines the performance of business organisations. There is a significant impact of customer 
relationship on project success and positively significant impact of technological turbulence as a moderator (Voss \& Kock, 2013). It is also empirically reported that technological turbulence has a significant moderating effect on the relationship between supplier market orientation and customer satisfaction (Terawatanavong, Whitwell, Widing, \& O'Cass, 2011). In the study of Wang and Feng (2012), a substantial moderating impact of market, technological and competitive intensity, was reported between quality management practices and business performance. It is also empirically reported that organizational performance was boosted up in highly turbulent markets (Yauch, 2010).

However, an insignificant moderating impact of competitive intensity, market and technological turbulence has been found between business performance and organizational best practices (Inman, Sale, Green, \& Whitten, 2011). Market turbulence and competitive intensity, weakens the relationship between business performance and market orientation (Jaakkola, 2015; Chong, Bian, \& Zhang, 2016). Environmental turbulence negatively influences the relation between export-orientation and export performance (Cadogan, Cui, \& Li, 2003). Firms operating in technologically turbulent environment, facing moderate competitive intensity, tend to collaborate more and that ultimately leads to growth. Similarly, those facing intense competition in less technologically turbulent surroundings, collaborate more and that eventually leads to better performance and growth of the firm (Ang, 2008).

From the past empirical studies reviewed, it can be deduced that there existed empirical gap within and outside Nigerian context regarding the moderating effect of environmental turbulence on the relationship between strategic agility and performance of oil and gas marketing companies in Lagos State, Nigeria. In the light of above empirical gap in literature reviewed, the following hypotheses were proposed for this study:

H1a: There is no significant relationship between strategic agility and firm performance of oil and gas marketing companies in Lagos State, Nigeria;

H2a: Strategic agility has no significant effect on firm performance of oil and gas marketing companies in Lagos State, Nigeria;

H3a: Environmental turbulence does not moderate the relationship between strategic agility and firm performance of oil and gas marketing companies in Lagos State, Nigeria.

\subsection{Theoretical Foundation}

Theoretically, the dynamic capability theory (DCT) was employed as the underpinning theory for this study.

Dynamic capabilities theory (DCT) was developed by Teece, Pisano, and Shuen (1997) and was defined as "the firm's ability to integrate, build, and reconfigure internal and external competences to address rapidly changing environments" (p. 516) and it examines how firms address or bring about changes in their turbulent business environment through reconfiguration of their firm-specific competencies into new competencies (Teece, 2007). In organisational theory, dynamic capability (DC) is the capability of an organisation to purposefully adapt an organisation's resource base. Eisenhardt and Martin (2000) defined dynamic capability as "the firm's processes that use resources-specifically the processes to integrate, reconfigure, gain and release resources-to match and even create market change" and "the organisational and strategic routines by which firms achieve new resources and configurations as markets emerge, collide, split, evolve, and die" (p. 1107).

The DCT addresses the highlighted shortcomings of the resource-based view (RBV) and resource dependence theory (RDT) and supersedes both theories in explaining how oganizations operate their resources with environmental uncertainty. Dynamic capabilities can be regarded as the ultimate organisational capabilities that are conducive to long term performance (Wang \& Ahmed, 2007). The dynamic capabilities and, therewith, the competitiveness of a company are determined by three factors: firstly, strategic paths, which refer to the availability of a spectrum of strategic options for a company and the path dependency of strategic options (Pisano, 2015); secondly, the resource position of a company, which refers to tangible but especially intangible assets; and finally, organisational processes in terms of management skills, patterns of behaviour, thinking and learning (Teece et al., 1997). In general, dynamic capabilities enable sustainable competitive advantage by focusing on strategy-relevant processes in companies and trying to improve responsiveness in a fast-changing environment. These dynamic capabilities reflect a company's ability to achieve new and innovative forms of competitive advantage given path dependencies and market positions (Teece et al., 1997). According to Teece (2007), this is achieved through sensing (identification and assessment of threats, opportunities, and customer needs), seizing (mobilization of resources to address fresh opportunities while capturing value from doing so) and transforming (ongoing organizational renewal). Strong dynamic capabilities do facilitate superior organizational performance arising from proper and useful analysis of business environment and technological opportunities, strong but change-oriented organizational culture, new product development and new process introduction (Teece, 2019). In this respect, the company's competitive advantage lies mainly in its dynamic 
capabilities, which refer to the capacity to build up strategic agility dimensions, possess strategic and forward-looking leadership, renew and reconfigure entrepreneurial capabilities and competences so as to achieve congruence with the changing business environment and ensure superior performance (Kyläheiko, Sandström, \& Virkkunen, 2002). Considering the assertion of the underpinning theory that entrepreneurial dynamic capabilities and competences enhance superior performance coupled with the objectives of this study, a conceptual model was formulated (See Figure 1).

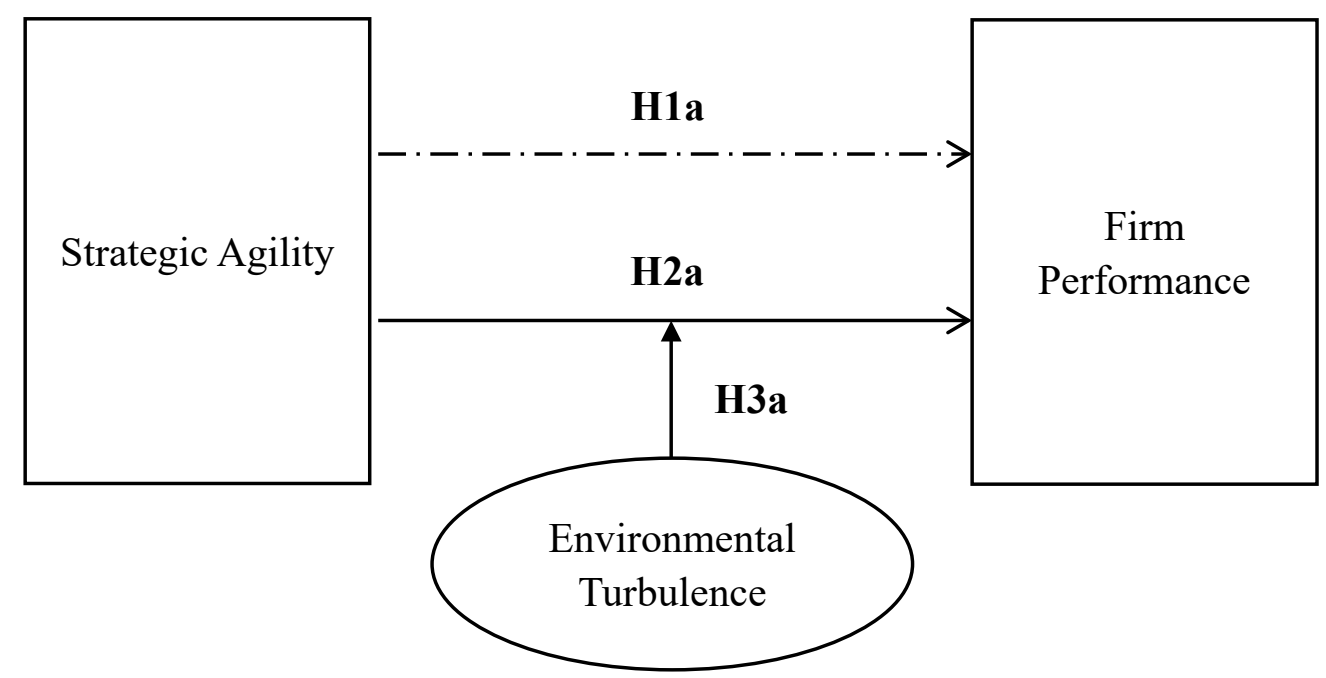

Figure 1.

Source: Researcher's Conceptual Model (2020)

The conceptual model depicted the link between strategic agility, firm performance as well as moderating effect of environmental turbulence on both strategic agility and firm performance; where strategic agility served as the independent variable, firm performance was dependent variable while environmental turbulence served as the moderating variable. In this study, the broken lines with H1a depicted the relationship between strategic agility and firm performance, the unbroken line with $\mathrm{H} 2 \mathrm{a}$ showed the effect of strategic agility on firm performance while the H3a depicted the moderating effect of environmental turbulence on the relationship between strategic agility and performance of the oil and gas marketing companies in Lagos State, Nigeria.

\section{Methodology}

This study employed survey research design to gather survey data on the study variables to examine the moderating effect of environmental turbulence on the relationship between strategic agility and firm performance of oil and gas marketing companies in Lagos State, Nigeria. The study focused on major oil and gas marketing companies in Lagos State, Nigeria such as NNPC Retail Ltd (NRL) and the other major petroleum products marketers like Conoil Plc, 11 Plc, Forte Oil Plc, MRS Oil Nigeria Plc, OVH Energy Marketing Ltd and Total Nigeria Plc. This study focused on filling station managers with total enumeration of 515 respondents. This study focused on Lagos State as the state consumes a significant large proportion of the petroleum products locally refined and imported into the country. In order to achieve main objective of this study, that is, the moderating effect of environmental turbulence on the strategic agility-performance relationship of oil and gas marketing companies in Lagos State, Nigeria, this study followed methodological process of hierarchical regression; firstly, established the relationship among study variables; secondly, established the effect among study variables and lastly, established the hierarchical effect among the study variables.

In this study, firm performance was the dependent variable, strategic agility served as the independent variable while environmental turbulence served as the moderator. For dependent, independent and moderating variables, a six-point modified Likert-type scale was used to elicit responses from every question in the questionnaire and this covered: Very High (VH)-6; High (H)-5; Moderately High (MH)-4; Moderately Low (ML)-3; Low (L)-2; Very Low (VL)-1. 
While those items in the questionnaire that failed reliability and validity test were removed from the questionnaire instrument and could not be used as part of items to measure study variables. The questionnaire instrument used for this study have passed through face validity, content validity, construct validity and reliability internal consistency test (See Table 1). Hence, the questionnaire instrument had been statistically certified to correctly and consistently measure the study variables. In this study, 480 questionnaires were retrieved and used for analysis out of 515 administered to the respondents, a response rate of $93.20 \%$.

3.1 The Validity and Reliability Result

Table 1. KMO, bartlett's test of sphericity and reliability result

\begin{tabular}{|c|c|c|c|c|c|}
\hline Variables & $\begin{array}{ll}\text { Number } & \text { of } \\
\text { Questions } & \\
\end{array}$ & $\begin{array}{l}\text { Kaiser-Meyer-Olkin } \\
\text { (KMO) }\end{array}$ & $\begin{array}{l}\text { Bartlett test of } \\
\text { Sphericity }\end{array}$ & $\begin{array}{l}\text { Cronbach's } \\
\text { Alpha }\end{array}$ & $\begin{array}{l}\text { Average Variance } \\
\text { Explained (AVE) }\end{array}$ \\
\hline Firm Performance & 6 & 0.593 & 0.000 & 0.724 & 0.712 \\
\hline Strategic Agility & 6 & 0.826 & 0.000 & 0.864 & 0.751 \\
\hline $\begin{array}{l}\text { Environmental } \\
\text { Turbulence }\end{array}$ & 5 & 0.746 & 0.000 & 0.785 & 0.704 \\
\hline
\end{tabular}

Source: Researchers' Computation (2020).

The questionnaire used for the study variables were tested for validity and reliability. The result in Table 1, shows that the KMO is greater than 0.5 . This means that the questions actually measured the variables in the study. The result of the Bartlett test of Sphericity at 0.000 which is less than $5 \%$, indicates that there was a high significant relationship among variables under study and that there is no redundancy between the variables that can be summarized with some factors. In this study, the KMO test was greater than 5\% and Bartlett test of Sphericity result was less than $5 \%$ indicating that statements that comprised the research instruments of each variable actually measured what were intended to be measured. The result of the KMO and Bartlett test of Sphericity are shown in Table 1. The construct validity of the research instrument was further established through confirmatory factor analysis. Average Variance Extracted (AVE) greater than 0.5 was used as an additional evidence of construct validity of all variables in the research instrument. The result of the Cronbach's alpha was greater than 0.70 for each of the variables which indicated that the items used to measure the study variables were reliable. To test whether multicollinearity would pose a serious challenge to the study, tests based on Variance Inflation Factor (VIF) and their reciprocal tolerances were conducted (See Table 2). Likewise, pearson correlation, regression and hierarchical regression methods of analyses were employed to test the three hypotheses of this study: 1a, 2a and 3a respectively.

\subsection{Model Specification}

The model was denoted based on the hypothesis of the study and stated as;

$\mathrm{Y}=$ Dependent Variable $=$ Firm Performance $(\mathrm{FP})$

$\mathrm{X}=$ Independent Variable $=$ Strategic Agility (SA)

$\mathrm{Z}=$ Moderating Variable $=$ Environmental Turbulence $(\mathrm{ET})$

The model formulated for the study was functionally written as follows based on the objective and hypothesis of the study:

$\mathrm{Y}=\mathrm{f}(\mathrm{X})$

$\mathrm{FP}=\mathrm{f}(\mathrm{SA})$

H1a: There is no significant relationship between strategic agility and firm performance of oil and gas marketing companies in Lagos State, Nigeria;

$\mathrm{Y}=\mathrm{f}(\mathrm{X})$

$\mathrm{Y}=\beta_{0}+\beta_{1} \mathrm{X}+\varepsilon_{\mathrm{i}}$

$\mathrm{FP}=\beta_{0}+\beta_{1} \mathrm{SA}_{\mathrm{i}}+\varepsilon_{\mathrm{i}}$

H2a: Strategic agility has no significant effect on firm performance of oil and gas marketing companies in Lagos State, Nigeria; and 
$\mathrm{Y}=\mathrm{f}(\mathrm{XZ})$

$\mathrm{Y}=\beta_{0}+\beta_{\mathrm{i}} \mathrm{X}+\beta_{\mathrm{z}} \mathrm{Z}+\beta_{\mathrm{iz}} \mathrm{XZ}+\varepsilon_{\mathrm{i}}$

$\mathrm{FP}=\beta_{0}+\beta_{\mathrm{i}} \mathrm{SA}_{\mathrm{i}}+\beta_{\mathrm{z}} \mathrm{ET}_{\mathrm{i}}+\beta_{\mathrm{iz}} \mathrm{SA} * \mathrm{ET}_{\mathrm{i}}+\varepsilon_{\mathrm{i}}$

H3a: Environmental turbulence does not moderate the relationship between strategic agility and firm performance of oil and gas marketing companies in Lagos State, Nigeria

Decision Criteria: If $\beta_{1} \& \beta_{\mathrm{iz}} \neq 0 \& \mathrm{p} \leq 0.05$, Reject null hypotheses;

Where $\beta_{0}$ =the constant term; $\beta_{\mathrm{i}}=$ the regression coefficient for SA; $\beta_{\mathrm{z}}=$ the regression coefficient for the multiplied moderator (SA*ET); while $\beta_{\mathrm{iz}}$ is the regression coefficient for moderator multiplied with independent variable (SA) and lastly, $\varepsilon_{\mathrm{i}}=$ Error Term.

\section{Result and Discussions}

This sub-section focused on multicollinearity test and hierarchical regression method of analysis.

\subsection{Multicollinearity Test}

Table 2. Multicollinearity test results

\begin{tabular}{llll}
\hline Variables & Tolerance & VIF & Remark \\
\hline Strategic Agility & 0.621 & 1.321 & No multicollinearity \\
Environmental Turbulence & 0.702 & 1.483 & No multicollinearity \\
\hline
\end{tabular}

Dependent Variable: Firm Performance.

Source: Survey Data (2020).

Table 2 shows that the variables have a VIF that is less than 10 and tolerance value more than 0.1 ruling out the possibility of multicollinearity. All the predictor variables had a VIF of less than 10 . The explanatory variables were not highly correlated and could not pose a serious problem. The data was thus suitable for hypotheses testing using pearson correlation, regression and hierarchical regression method of analyses.

H1a: There is no significant relationship between strategic agility and firm performance of oil and gas marketing companies in Lagos State, Nigeria

Table 3. Correlation result for hypothesis (H1a)

\begin{tabular}{llll}
\hline & & Firm Performance & Strategic Agility \\
\hline \multirow{3}{*}{ Firm Performance } & Pearson Correlation & 1 & $.721^{* *}$ \\
& Sig. (2-tailed) & & .000 \\
& $\mathrm{~N}$ & 479 & 479 \\
Strategic Agility & Pearson Correlation & $.721^{* *}$ & 1 \\
& Sig. (2-tailed) & .000 & \\
& $\mathrm{~N}$ & 479 & 479 \\
\hline
\end{tabular}

Correlation is significant at the 0.05 level (2-tailed).

Source: Author's Computation from Field Survey Data Analysis (2020).

The relationship between strategic agility and firm performance was investigated in oil and gas marketing companies in Lagos State, Nigeria using Pearson's product-moment correlation coefficient. The results show that there is a strong, positive relationship between firm performance and strategic agility with a correlation coefficient of 0.721 respectively, which implies firm performance may increase with an improvement in strategic agility of oil and gas 
marketing companies in Lagos State, Nigeria. The corresponding p-value is less than 0.05 implying that the result is statistically significant. Therefore, the null hypothesis one (Hla) which states that strategic agility has no significant relationship with the firm performance of oil and gas marketing companies in Lagos State, Nigeria was rejected.

H2a: Strategic agility has no significant effect on firm performance of oil and gas marketing companies in Lagos State, Nigeria

Table 4a. Model Summary of Effect of Strategic Agility on Firm Performance of Selected Oil and Gas Marketing Companies in Lagos State, Nigeria

\begin{tabular}{lllll}
\hline Model & R & R Square & Adjusted R Square & Std. Error of the Estimate \\
\hline 1 & $0.781^{\mathrm{a}}$ & 0.610 & 0.609 & 10.060 \\
\hline
\end{tabular}

a. Predictors: (Constant), Strategic Agility.

Table 4b. ANOVA for Strategic Agility and Firm Performance

\begin{tabular}{lllllll}
\hline Model & & Sum of Squares & Df & Mean Square & F & Sig. \\
\hline \multirow{3}{*}{1} & Regression & 75556.117 & 1 & 75556.117 & 746.623 & $.000^{\mathrm{b}}$ \\
& Residual & 48372.249 & 478 & 101.197 & & \\
& Total & 123928.367 & 479 & & & \\
\hline
\end{tabular}

a. Dependent Variable: Firm Performance.

b. Predictors: (Constant), Strategic Agility.

Table 4c. Regression coefficients of effects of strategic agility on firm performance

\begin{tabular}{|c|c|c|c|c|c|c|}
\hline \multirow{2}{*}{\multicolumn{2}{|c|}{ Model }} & \multicolumn{2}{|c|}{ Unstandardised Coefficients } & \multirow{2}{*}{$\begin{array}{l}\text { Standardised Coefficients } \\
\text { Beta }\end{array}$} & \multirow{2}{*}{$\mathrm{t}$} & \multirow{2}{*}{ Sig. } \\
\hline & & B & Std. Error & & & \\
\hline \multirow{2}{*}{1} & (Constant) & 70.868 & 7.673 & & 9.236 & 0.000 \\
\hline & Strategic Agility & 0.911 & 0.033 & 0.781 & 27.324 & 0.000 \\
\hline
\end{tabular}

a. Dependent Variable: Firm Performance.

Source: Researcher's Results (2020).

Table 4a show that there is a strong and positive relationship between strategic agility and firm performance of selected oil and gas marketing companies in Lagos State, Nigeria as shown by correlation coefficient $R$ of 0.781 . The coefficient of determination ( $\mathrm{R}$ square) in the table is 0.610 . This value indicates that $61 \%$ change in firm performance of selected oil and gas marketing companies is explained by the strategic agility practices put in place by these organisations. The results obtained is also reliable as given by the Adjusted R value of 0.609 which explains that the results are $60.9 \%$ reliable and therefore the regression model developed can be relied on to explain the trends in the firm performance of the selected oil and gas marketing companies. In addition, Table $4 \mathrm{~b}$ presents the result of ANOVA which shows the reliability of the model developed in explaining the effect of strategic agility on firm performance. The significance of the model was tested at $5 \%$ level of significance. From the result, F-statistic is 746.623 with p-value of 0.000 which indicates that the regression model developed is statistically significant and can be relied upon to explain the effect of strategic agility on firm performance of selected oil and gas marketing companies. Lastly, Table $4 \mathrm{c}$ presents regression coefficients. The results in the table revealed that the coefficient is positive and statistically significant at $5 \%$ level $(\beta=0.911, \mathrm{p}<0.05)$. The $t$-statistic and the corresponding $\mathrm{p}$-value are 27.324 and 0.000 respectively. This implied that strategic agility has a positive and significant effect on firm performance of selected oil and gas marketing companies in Lagos State, Nigeria. This indicates that firm performance of selected oil and gas marketing companies increase significantly when strategic agility is increased. 
Therefore, the null hypothesis two (H2a) which states that strategic agility does not significantly affect firm performance of selected oil and gas marketing companies in Lagos State, Nigeria was rejected.

H3a: Environmental turbulence does not moderate the relationship between strategic agility and firm performance of oil and gas marketing companies in Lagos State, Nigeria

Table 5a. Model summary

\begin{tabular}{|c|c|c|c|c|c|c|c|c|c|}
\hline \multirow[b]{2}{*}{ Model } & \multirow[b]{2}{*}{$\mathbf{R}$} & \multirow{2}{*}{$\begin{array}{l}\text { R } \\
\text { Square }\end{array}$} & \multirow{2}{*}{$\begin{array}{l}\text { Adjusted } \\
\text { R Square }\end{array}$} & \multirow{2}{*}{$\begin{array}{l}\text { Std. Error of } \\
\text { the Estimate }\end{array}$} & \multicolumn{5}{|c|}{ Change Statistics } \\
\hline & & & & & $\begin{array}{l}\text { R Square } \\
\text { Change }\end{array}$ & F Change & df1 & df2 & Sig. F Change \\
\hline 1 & $0.781^{\mathrm{a}}$ & 0.610 & 0.609 & 0.62541254 & 0.610 & 746.623 & 1 & 478 & 0.000 \\
\hline 2 & $0.793^{b}$ & 0.629 & 0.627 & 0.61049791 & 0.019 & 24.641 & 1 & 477 & 0.000 \\
\hline 3 & $0.833^{\mathrm{c}}$ & 0.693 & 0.692 & 0.61105296 & 0.066 & 21.134 & 1 & 476 & 0.001 \\
\hline
\end{tabular}

a. Predictors: (Constant), Strategic Agility.

b. Predictors: (Constant), Strategic Agility, Environmental Turbulence.

c. Predictors: (Constant), Strategic Agility, Environmental Turbulence, Strategic Agility x Environmental Turbulence.

d. Dependent Variable: Firm Performance.

Table 5b. ANOVA

\begin{tabular}{|c|c|c|c|c|c|c|}
\hline \multicolumn{2}{|c|}{ Model } & \multirow{2}{*}{$\begin{array}{l}\text { Sum of Squares } \\
292.035\end{array}$} & \multirow{2}{*}{$\begin{array}{l}\text { Df } \\
1\end{array}$} & \multirow{2}{*}{$\begin{array}{l}\text { Mean Square } \\
292.035\end{array}$} & \multirow{2}{*}{$\begin{array}{l}\text { F } \\
746.623\end{array}$} & \multirow{2}{*}{$\begin{array}{l}\text { Sig. } \\
.000^{\mathrm{b}}\end{array}$} \\
\hline & Regression & & & & & \\
\hline 1 & Residual & 186.965 & 478 & .391 & & \\
\hline & Total & 479.000 & 479 & & & \\
\hline \multirow{3}{*}{2} & Regression & 301.218 & 2 & 150.609 & 404.095 & $.000^{\mathrm{c}}$ \\
\hline & Residual & 177.782 & 477 & .373 & & \\
\hline & Total & 479.000 & 479 & & & \\
\hline \multirow{3}{*}{3} & Regression & 301.268 & 3 & 100.423 & 268.952 & $.000^{\mathrm{d}}$ \\
\hline & Residual & 177.732 & 476 & .373 & & \\
\hline & Total & 479.000 & 479 & & & \\
\hline
\end{tabular}

a. Dependent Variable: Firm Performance.

b. Predictors: (Constant), Strategic Agility.

c. Predictors: (Constant), Strategic Agility, Environmental Turbulence.

d. Predictors: (Constant), Strategic Agility, Environmental Turbulence, Strategic Agility x Environmental Turbulence. 
Table 5c. Coefficients

\begin{tabular}{|c|c|c|c|c|c|c|}
\hline \multirow{2}{*}{\multicolumn{2}{|c|}{ Model }} & \multicolumn{2}{|c|}{$\begin{array}{l}\text { Unstandardized } \\
\text { Coefficients }\end{array}$} & \multirow{2}{*}{$\begin{array}{l}\text { Standardized } \\
\text { Coefficients } \\
\text { Beta }\end{array}$} & \multirow[t]{2}{*}{$\mathbf{t}$} & \multirow[t]{2}{*}{ Sig. } \\
\hline & & B & Std. Error & & & \\
\hline \multirow{2}{*}{1} & (Constant) & $3.606 \mathrm{E}-15$ & 0.029 & & .000 & 1.000 \\
\hline & Strategic Agility & .781 & 0.029 & 0.781 & 27.324 & 0.000 \\
\hline \multirow{3}{*}{2} & (Constant) & $2.364 \mathrm{E}-15$ & 0.028 & & .000 & 1.000 \\
\hline & Strategic Agility & 0.679 & 0.035 & 0.679 & 19.597 & 0.000 \\
\hline & Environmental Turbulence & -0.017 & 0.003 & -0.172 & -4.964 & 0.000 \\
\hline \multirow{4}{*}{3} & (Constant) & 0.005 & 0.031 & & .155 & 0.877 \\
\hline & Strategic Agility & 0.677 & 0.035 & 0.677 & 19.214 & 0.000 \\
\hline & Environmental Turbulence & -0.017 & -0.003 & -0.173 & -4.971 & 0.000 \\
\hline & Strategic Agility x Environmental Turbulence & 0.031 & 0.002 & -0.190 & 15.466 & 0.001 \\
\hline
\end{tabular}

a. Dependent Variable: Firm Performance.

Source: Researcher's Results (2020).

Tables 5(a-c) present hierarchical multiple regression results for the moderating effect of environmental turbulence on the relationship between strategic agility and firm performance. Results in Table 5a summarize the output for the analysis if moderation effect is not considered. In this model, the independent variable was strategic agility and the dependent variable is firm performance. From Table 5a, Model 1 reveals that $\mathrm{R}=0.781, \mathrm{R}^{2}=0.610$ and $[\mathrm{F}(1,478)=$ $746.623, \mathrm{p}=.0001]$. The value of coefficient of determination, $\mathrm{R}^{2}$ indicates that $61 \%$ of the variance in the firm performance of selected oil and gas marketing companies in Lagos State was accounted by strategic agility. The remaining $39 \%$ of the total variation in firm performance are explained by factors not included in the model. The adjusted R-squared value was found to be 0.609 . The explained variation in the relationship was found to be significant $(\mathrm{p}=0.001<0.05)$. The regression coefficients section in Table 5 a model 1 shows that the coefficient and constants were not only positive but also significant $(\mathrm{p}<0.05)$. Thus, the model gives the significant effect of strategic agility on firm performance.

In the second step, a multiple regression involving strategic agility and environmental turbulence was introduced in the model as predictor variables and the results indicate that adjusted R-squared is 0.629 implying that the regression model explains $62.9 \%$ of changes in firm performance while the rest are attributed to variables not included in the regression. The F-statistics is 404.095 with a corresponding $p$-value of $0.000(p<0.05)$ indicating that the influence is significant. Strategic agility has a coefficient of 0.679 ; t-statistic of 19.597 and a p-value of 0.000 which implies that a unit change in strategic agility would result in a 0.679 unit change in firm performance. The beta coefficient for environmental turbulence is-0.172; t-statistic of 4.964 and a corresponding p-value of $0.000(p<0.05)$. This implies that environmental turbulence has a significant negative influence on firm performance of selected oil and gas marketing companies in Lagos State. The result implies that a unit change in environmental turbulence would result in 0.172 decrease in firm performance.

The third step involved the interaction term between strategic agility and environmental turbulence using regression model. Result in Table 5c indicates that the R-square change is 0.066 , and F-change of 21.134 with a corresponding p-value of 0.001 implying that the overall interaction of strategic agility and environmental turbulence has a significant negative influence on firm performance of selected oil and gas marketing companies in Lagos State $(p<0.05)$. Furthermore, the interaction term of strategic agility and environmental turbulence has a beta coefficient of -0.190 and a corresponding p-value of 0.001 which implies that the relationship is statistically significant and negative $(p<0.05)$. Hence, environmental turbulence moderated the relationship between strategic agility and firm performance of selected oil and gas marketing companies, and the relationship is found to be negative. The results show that environmental turbulence has a significant moderating effect on the relationship between strategic agility and firm performance of selected oil and gas marketing companies. Based on this result, the null hypothesis three (H3a) which states that environmental turbulence has no significant moderating effect on the relationship between 
strategic agility and firm performance of selected oil and gas marketing companies in Lagos State, Nigeria was rejected.

\subsection{Discussion}

Following the three hypotheses (H1a, H2a \& H3a) stated in this study, it is shown that strategic agility significantly related with and affected firm performance as well as environmental turbulence significantly moderated the relationship between strategic agility and firm performance of selected oil and gas marketing companies in Lagos State, Nigeria. Supporting these claims, several empirical studies such as Salih and Alnaji (2014), Tikkanen (2014), Sudon, Abareshi, and Pittayachawan (2015) and Chirchir (2015) found that strategic agility are goal drivers that enable organisations to deal with the environmental changes and thus improve organisational performance. Similarly, Al-Romeedy (2019) and Okotoh (2015) found that strategic agility has positive relationship with competitive advantage and significantly affects overall firm performance. They also revealed that the relationship is through delivery reliability, innovation, then process flexibility, service quality and finally cost leadership. Muthoni (2015) and Okotoh (2015) found that strategic agility has positive and significant effect on firm competitive capability and operational performance. Claub et al. (2019) and Ravichandran (2018) established that strategic agility significantly improved overall firm performance. Furthermore, Khan, and Wisner (2019) established that strategic agility had significant impact on firm performance. Similarly, Tse et al. (2016) revealed that firms that are more concerned about learning, are more agile and more responsive to uncertainties, thus significantly enhancing firm performance. Bratianu (2015) and Hadad (2017) revealed that having strategic agility and thinking represents a competitive advantage to secure the future position and performance of an organisation in the market. They also revealed that strategic agility and thinking supports the development of new business opportunities, boosts value and performance within the organisation. On the contrary, Djaja and Arief (2015) found that strategic agility has negative impact on firm profitability and Ojha (2008) revealed that increases in strategic agility did not have any positive effect on firm financial performance but enhances the competitive capabilities of organisations' operations.

Finally, scholars claimed that as firms become more proactive and active in their responses to forces in the business environment, they take advantage of the opportunities before competitors and arrest the likely threats before they make negative impacts on the businesses through agile measures like strategic sensitivity and strategic response, thus enhancing performance (Doz \& Kosonen, 2010; Denning, 2016; Murungi, 2015; Tabe-Khoshnood \& Nematizadeh, 2017). Kwon et al. (2018) found that rapid changes in firms' external and internal environments are related to successful opportunity pursuit; Nzewi and Moneme (2016) established that business agility is that unique capability that assures competitive advantage in a rapid and unpredictable business environment; while Ojha (2008) found that strategic agility is useful in moderate levels of environmental turbulence but not when turbulence is low or extremely high.

Theoretically, the dynamic capability theory supported the study findings that enterprises' responsiveness, agility and innovativeness become timely, rapid and flexible in dynamic markets, thus improving overall firm performance. The theory further stated that firms with greater dynamic capabilities and strategic agility will strategically overcome threats from business environmental turbulence and outperform firms with smaller dynamic capabilities. The theory creates and sustains an operational performance over other firms by responding to and creating environmental changes. Capabilities are a collection of high level, learned, patterned, repetitive behaviors that an organisation can perform better relative to its competition (Winter, 2003). Dynamic capabilities help firm's sense opportunities and then seize them by successfully reallocating resources, often by adjusting existing competencies or developing new ones in order to achieve overall firm performance. Literature has regarded strategic agility as a higher-order dynamic capability. Tikkanen (2014) observed that dynamic capabilities do influence parts of strategic agility in a dynamic industry; Teece, Peteraf, and Leih (2016) asserted that strong dynamic capabilities are necessary for fostering the organizational agility necessary to address deep environmental uncertainty; and Hemmati, Feiz, Jalilvand, and Kholghi (2016) regarded strategic agility as a dynamic capability in developing a framework for competitive advantage by systematic quantitative methodology. Their study confirmed the intermediate role of strategic agility as a dynamic capability between resources and competitive advantage. Di Minin, Frattini, Bianchi, Bortoluzzi, and Piccaluga (2014) acknowledged strategic agility as a critical dynamic capability necessary to achieve long-term competitive advantage in highly dynamic and turbulent industries; this is more so in situations where the need arises to strike a balance between divergent strategic objectives but with limited resources.

\section{Conclusion and Recommendations}

The study concluded that strategic agility related with and affected performance of oil and gas marketing companies in Lagos State, Nigeria. Also, the study concluded that environmental turbulence moderated the relationship between 
strategic agility and performance of these oil and gas marketing companies. Therefore, this study recommended that the oil and gas marketing companies should:

1) Fully and dynamically embrace strategic agility practices as this will improve their performance over their competitors.

2) More specifically, continuously develop their capabilities for proper and timely sensing of changes in their business environment including useful analysis of data from there.

3) Install proper capacity building infrastructure for identifying the emerging opportunities from the environment ahead of competition.

4) Continuously employ fast strategies in responding to the emerging signals from the environment in order to increase their organisations' competitive capabilities.

5) Give maximum consideration for local and global business environmental turbulence factors in strategic planning in order to survive and achieve overall firm performance.

6) Be proactive in handling emerging signals from the larger environment and where they have to be reactive, it should be with speed.

7) Note that strategic agility is not a once-and-for-all strategy but a continuous way of business life. Therefore, these companies should continuously sustain their strategic agility initiatives including analysing the drivers of and motivations for environmental turbulence, opportunity identification and formulation of alternative strategic decisions for opportunity exploitation which will enable them to sustain their superior firm performance on all indicators.

\section{Limitations and Suggestion for Further Study}

There are certain limitations inherent in the study which must be identified and form the basis of further studies in this area. First, the population of 515 stations used in the study was small relative to the total stations in Lagos State and in the country as a whole. A larger sample will enhance the coverage of the study to other areas of the sector. Second, the scope of the study was limited to the major oil and gas marketers and excluded the independent marketers of petroleum products in Lagos State, Nigeria. Though this group have a fair share of the market but were excluded from the sample because they operate a different business model from the major marketers. Third, the oil and gas marketing sector belong to the downstream end of the industry and thus excluded the upstream sector which comprises of oil and gas exploration and production; hence, the study findings cannot be generalized for the industry as a whole.

Further studies should: (i) examine the engagement of strategic agility initiatives in the upstream sector of the oil and gas industry and compare the results; (ii) investigate how the study variables apply to the independent marketers of petroleum products and carry out a comparative analysis; (iii) analyse and investigate which of the components of environmental turbulence (complexity, dynamism and munificence) has the greatest moderating effect on the relationship between the study variables; and (iv) examine how and to what extent is the moderating impact of environmental turbulence on the relationship between strategic agility and performance of the upstream operators and compare with the results of this study. This is all the more critical in view of the degree of interaction that takes place between the upstream sector and external factors.

\section{References}

Abbas, M. W., \& Hassan, M. (2017). Moderating impact of environmental turbulence on relationship between business innovation and business performance. Pakistan Journal of Commerce and Social Sciences, 11(2), 576-596. Retrieved from http://hdl.handle.net/10419/188306

Al-Romeedy, B. S. (2019). Strategic agility as a competitive advantage in airlines-Case study: Egypt Air. Journal of the Faculty of Tourism and Hotels-University of Sadat City, 3(1), 1-15.

Amin-Beidokhti, A. A., \& Zargar, S. M. (2012). Pathology of small and medium enterprises (SMEs) and practical strategies to support them (Semnan Province Case Study). Quarterly Journal of Management and Development Process, 24(4), 125-156. Retrieved from https://www.sid.ir/en/journal/ViewPaper.aspx?id=374833

Ang, S. H. (2008). Competitive intensity and collaboration: Impact on firm growth across technological environments. Strategic Management Journal, 29(10), 1057-1075. https://doi.org/10.1002/smj.695

Anggraini, W., \& Sudhartio, L. (2019). Strategic agility in environmental turbulence: A case of banking sector in Indonesia. Proceedings of the 1st Sampoerna University-AFBE International Conference, SU-AFBE 2019, 6-7 December 2019, Jakarta Indonesia. https://doi.org/10.4108/eai.6-12-2018.2286279 
Arokodare, M.A. (2020). Strategic agility and firm performance of selected oil and gas marketing companies in Lagos State, Nigeria (Unpublished Doctoral Thesis, Babcock University, Nigeria).

Arokodare, M. A., \& Asikhia, O. U. (2020a). The moderating effect of external environment on the relationship between strategic entrepreneurship and performance of selected oil and gas service firms in Lagos and Rivers States, Nigeria. Review of European Studies, 12(2), 62-85. https://doi.org/10.5539/res.v12n2p85

Arokodare, M. A., \& Asikhia, O. U. (2020b). Entrepreneurial orientation as a determinant of oil and gas service firm performance in Nigeria: The moderating role of external environment. Journal of Management and Strategy, 11(2), 1-17. https://doi.org/10.5430/jms.v11n2p1

Arokodare, M. A., Asikhia, O. U., \& Makinde, G. O. (2019). Strategic agility and firm performance: The moderating role of organizational culture. Business Management Dynamics, 9(3), 1-12. Retrieved from http://bmdynamics.com/issue_pdf/bmd110711-01-12.pdf

Ashori, H., Veisari, E. F., \& Taghavi, S. A. (2015). The relationship between the organization agility and mental health of staff on strategic preparation for crisis management: The case study in Islamic Azad Universities of Mazandaran. International Journal of Management Sciences, 6(5), 272-281. RePEc:rss:jnljms:v6i5p4

Awino, Z. B. (2011). Strategic management: An empirical investigation of selected strategy variables on firms performance: A study of supply chain management in large private manufacturing firms in Kenya. Prime Journals Business Administration Management (BAM), 1(2), 26-31.

Boyne, G. A., \& Meier, K. J. (2009). Environmental turbulence, organizational stability, and public service performance. Administration \& Society, 40(8), 799-824. https://doi.org/10.1177/0095399708326333.

Brătianu, C. (2015). Developing strategic thinking in business education. Management Dynamics in the Knowledge Economy, 3(3), 409-429.

Cadogan, J. W., Cui, C. C., \& Kwok Yeung Li, E. (2003). Export market-oriented behavior and export performance: The moderating roles of competitive intensity and technological turbulence. International Marketing Review, 20(5), 493-513. https://doi.org/10.1108/IMR-08-2016-0167

Cegarra-Navarro, J. G., Soto-Acosta, P., \& Wensley, A. K. (2016). Structured knowledge processes and firm performance: The role of organisational agility. Journal of Business Research, 69(5), 1544-1549. https://doi.org/10.1016/j.jbusres.2015.10.014

Chirchir, E. (2015). Relationship between organisational agility and operational productivity at Kenya Ports Authority (Unpublished MBA project, University of Nairobi).

Chong, W. K., Bian, D., \& Zhang, N. (2016). E-marketing services and e-marketing performance: the roles of innovation, knowledge complexity and environmental turbulence in influencing the relationship. Journal of Marketing Management, 32(1-2), 149-178. https://doi.org/10.1080/0267257X.2015.1102758

Claub, T., Abebe, M., Tangpong, C., \& Hock, M. (2019). Strategic agility, business model innovation, and firm performance: An empirical investigation. Institute of Electrical and Electronics Engineers Transactions on Engineering Management, 99, 1-18. https://doi.org/10.1109/TEM.2019.2910381

Davidsson, P. (2004). Researching Entrepreneurship. Boston, MA: Springer.

Denning, S. (2016). Christensen updates disruption theory. Strategy \& Leadership, 44(2), 10-16. https://doi.org/10.1108/SL-01-2016-0005

Di-Minin, A., Frattini, F., Bianchi, M., Bortoluzzi, G., \& Piccaluga, A. (2014). Udinese Calcio soccer club as a talents factory: Strategic agility, diverging objectives, and resource constraints. European Management Journal, 32(2), 319-336. https://doi.org/10.1016/j.emj.2013.04.001

Djaja, I., \& Arief, M. (2015). The impact of dynamic information technology capability and strategic agility on business model innovation and firm performance on ICT firms. Advanced Science Letters, 21(5), 1225-1229. https://doi.org/10.1166/asl.2015.6105

Doz, Y., \& Kosonen, M. (2008). Fast Strategy: How Strategic Agility Will Help You Stay Ahead of the Game. Philadelphia: Wharton School Publishing.

Doz, Y. L., \& Kosonen, M. (2010). Embedding strategic agility: A leadership agenda for accelerating business model renewal. Long Range Planning, 43(2-3), 370-382. https://doi.org/10.1016/j.lrp.2009.07.006

Egbunike, C. F., \& Okerekeoti, C. U. (2018). Macroeconomic factors, firm characteristics and financial performance. Asian Journal of Accounting Research, 3(2), 142-168. https://doi.org/10.1108/AJAR-09-2018-0029 
Ehie, I., \& Muogboh, O. (2016). Analysis of manufacturing strategy in developing countries: A sample survey of Nigerian manufacturers. Journal of Manufacturing Technology Management, 27(2), 234-260. https://doi.org/10.1108/JMTM-07-2014-0094

Eisenhardt, K. M., \& Martin, J. A. (2000). Dynamic capabilities: What are they? Strategic Management Journal, 21(10-11), https://doi.org/10.1002/1097-0266(200010/11)21:10/11<1105::AID-SMJ133>3.0.CO;2-E

1105-1121.

Garbie, I. H. (2011). Implementation of agility concepts into oil industry. Journal of Service Science and Management, 4, 203-214. https://doi.org/10.4236/jssm.2011.42024

Gathenya, J. W. (2012). Entrepreneurial strategic planning practices and firm performance among women-led small and medium enterprises in Kenya ( $\mathrm{PhD}$ Thesis, Jomo Kenyatta University of Agriculture and Technology).

Hadad, S. (2017). Knowledge economy: Characteristics and dimensions. Management Dynamics in the Knowledge Economy, 5(2), 203-225. https://doi.org/10.25019/MDKE/5.2.03

Hemmati, M., Feiz, D., Jalilvand, M. R., \& Kholghi, I. (2016). Development of fuzzy two-stage DEA model for competitive advantage based on RBV and strategic agility as a dynamic capability. Journal of Modelling in Management, 11(1), 288-308. https://doi.org/10.1108/JM2-12-2013-0067

Ibidunni, O. S., \& Ogundele, O. J. K. (2013). Competition in marketing: Survival yardstick for small and medium enterprises in Nigeria. Mediterranean Journal of Social Sciences, 4(1), 231-240.

Inman, R. A., Sale, R. S., Green Jr, K. W., \& Whitten, D. (2011). Agile manufacturing: Relation to JIT, operational performance and firm performance. Journal of Operations Management, 29(4), 343-355. https://doi.org/10.1016/j.jom.2010.06.001

Jaakkola, M. (2015). Market-driven innovation capability and financial performance: Moderating effect of environmental turbulence. The Sustainable Global Marketplace, 320-320. https://doi.org/10.1007/978-3-319-10873-5_184

Jahanshahi, A. A., Rezaei, M., Nawaser, K., Ranjbar, V., \& Pitamber, B. K. (2012). Analyzing the effects of electronic commerce on organisational performance: Evidence from small and medium enterprises. African Journal of Business Management, 6(22), 6486-6496. https://doi.org/10.5897/AJBM11.1768

Jones, G. R., \& Charles, W. L. (2010). Strategic Management: An Integrated Approach (9th ed.). South-Western Publisher.

Khorshid, S. (2019). The impact of organisation's strategic agility and emotional capability on entrepreneurship orientation (Case study: The university of Khashan and Qom cities). Management in the Islamic University, 14(6), 238-262. Retrieved from https://www.sid.ir/en/journal/ViewPaper.aspx?id=576016

Kim, J. (2018). A study on the effect of environmental turbulence on the agility of government agencies and the effect of agility on the organizational performance. Journal of Product Research, 36(1), 19-27. https://doi.org/10.36345/kacst.2018.36.1.003

Khan, H., \& Wisner, J. D. (2019). Supply chain integration, learning, and agility: Effects on performance. Journal of Operations and Supply Chain Management, 12(1), 14-23. https://doi.org/10.31387/oscm0360218

Kwon, S. J., Ryu, D., \& Park, E. (2018). The influence of entrepreneur's strategic agility and dynamic capability on the opportunity pursuit process of new ventures: Evidence from South Korea. Academy of Strategic Management Journal, 17(1), 1-17.

Kyläheiko, K., Sandström, J., \& Virkkunen, V. (2002). Dynamic capability view in terms of real options. International Journal of Production Economics, 80(1), 65-83. https://doi.org/10.1016/S0925-5273(02)00244-X

Lebans, M., \& Euske, K. (2006). Conceptual and operational delineation of performance: Business performance measurement. Cambridge University Press.

Lin, X., \& Germain, R. (2003). Product quality orientation and its performance implications in Chinese state-owned enterprises. Journal of International Marketing, 11(2), 59-78. https://doi.org/10.1509/jimk.11.2.59.20166

Mavengere, N. B. (2013). Information technology role in supply chain's strategic agility. International Journal of Agile Systems and Management, 6(1), 7-24. https://doi.org/10.1504/IJASM.2013.052209

Musyoka, S. M. (2016). Factors that influence organisational performance in the hospitality industry: A case study of Sankara Nairobi (A MBA Project Report, Chandaria School of Business). 
Muthoni, A. M. (2015). Influence of strategic agility on competitive capability of private universities in Kenya (Unpublished MBA Project, University of Nairobi).

Nafei, W. A. (2016). Organisational agility. The key to organisational success. International Journal of Business and Management, 11(5), 296-309. https://doi.org/10.5539/ijbm.v11n5p296

Nnamani, E., \& Ajagu, H.E. (2014). Environmental factors and organisational performance in Nigeria: A study of Juhel Company. World Engineering \& Applied Sciences Journal, 5(3), 75-84. 10.5829/idosi.weasj.2014.5.3.1124

Nzewi, H. N., \& Moneme, P. (2016). Business agility and competitive advantage of selected commercial banks in Anambra State, Nigeria. Pyrex Journal of Business \& Finance Management Research, 2(8), 81-88.

Ogah, M. S. (2018). Productivity and employee behavior change strategies in two Nigerian manufacturing organizations (Unpublished Doctoral Dissertation, Walden University, Minneapolis, MN).

Oginni, B. O., \& Adesanya, A. S. (2013). Business environmental factors: Implications on the survival and growth of business organisations in the manufacturing sector of Lagos Metropolis. Business and Management Research, 2(3), 146-153. https://doi.org/10.5430/bmr.v2n3p146

Ojha, D. (2008). Impact of strategic agility on competitive capabilities and financial performance (Doctoral dissertation, Clemson University).

Ojo, E. O., \& Ajayi, A. T. (2017). From Balewa to Buhari: The paradox of Nigeria's underdevelopment. The Journal of Social, Political, and Economic Studies, 42(2), 180-227. Retrieved from http://www.jspes.org/

Okotoh, A. K. (2015). Influence of organisational agility on operational performance of Trademark East Africa (A Master Thesis, University of Nairobi).

Olanipekun, W. D., Abioro, M. A., Akanni, L. F., Arulogun, O. O., \& Rabiu, R. O. (2015). Impact of Strategic Management on Competitive Advantage and Organisational Performance-Evidence from Nigerian Bottling Company. Journal of Policy and Development Studies, 289(1850), 1-14. https://doi.org/10.12816/0011216

Oyedijo, A. (2012). Strategic agility and competitive performance in the Nigerian telecommunication industry: an empirical investigation. American International Journal of Contemporary Research, 2(3), 227-237.

Oyerinde, A. J., Olatunji, O. C., \& Adewale, O. A. (2018). Corporate social responsibility and performance of oil and gas industry in Nigeria. EKSU Journal of the Management Scientists, 2(1), 97-106.

Pavlou, P. A., \& Sawy, E. O. A. (2011). Understanding the elusive black box of dynamic capabilities. Decision Sciences, 42(1), 239-273. https://doi.org/10.1111/j.1540-5915.2010.00287.x

Power, B., \& Reid, G. C. (2005). Flexibility, firm-specific turbulence and the performance of the long-lived small firm. Review of Industrial Organization, 26(4), 415-443. https://doi.org/10.1007/s11151-005-0224-5

Pisano, G. P. (2015). A normative theory of dynamic capabilities: Connecting strategy, know-how, and competition. Working Paper 16-036, Harvard Business School. https://doi.org/10.2139/ssrn.2667018

Pratono, A. H., \& Mahmood, R. (2014). The moderating effect of environmental turbulence in the relationship between entrepreneurial management and firm performance. Universal Journal of Management, 2(7), 285-292. https://doi.org/10.13189/ujm.2014.020704

PricewaterhouseCoopers (2018). Taking on tomorrow: Africa oil and gas review. Retrieved from www.pwc.co.za/oil-gas-review.

Qin, R., \& Nembhard, D. A. (2015). Workforce agility in operations management. Surveys in Operations Research and Management Science, 20(2), 55-69. https://doi.org/10.1016/j.sorms.2015.11.001

Reid, D. M., \& Zyglidopoulos, S. C. (2004). Causes and consequences of the lack of strategic foresight in the decisions of multinational enterprises to enter China. Futures, 36(2), 237-252. https://doi.org/10.1016/S0016-3287(03)00150-2

Rimita, K. N. (2019). Leader readiness in a volatile, uncertain, complex and ambiguous business environment. $\mathrm{PhD}$ Thesis. Walden University. https://doi.org/10.5590/JOSC.2020.12.1.02

Salih, A. A., \& Alnaji, L. (2014). Impact of strategic thinking and strategic agility on strategic performance: A case study of Jordanian insurance industry companies. International Review of Management and Business Research, 3(4), 1871-1882. https://www.irmbrjournal.com/papers/1418115238.pdf 
Sudon, A., Abareshi, P., \& Pittayachawan, S. (2015). Agility enablers, capabilities and performance: Thai automotive part industry. Journal of Business Research, 65(56), 579-585.

Syafarudin, A. (2016). Strategy of leadership and innovation in improving company performance against competitive advantage: A case study of PT. Pegadaian (Ltd) in Indonesia. International Journal of Economics, Commerce and Management, 4(6), 471-482. http://ijecm.co.uk/wp-content/uploads/2016/06/4627.pdf

Tabe-Khoshnood, N., \& Nematizadeh, S. (2017). Strategic agility and its impact on the competitive capabilities in Iranian private banks. International Journal of Business and Management, 12(2), 220-229. https://doi.org/10.5539/ijbm.v12n2p220

Teece, D. J. (2007). Explicating dynamic capabilities: The nature and microfoundations of (sustainable) enterprise performance. Strategic Management Journal, 28(13), 1319-1350. https://doi.org/10.1002/smj.640

Teece, D. J. (2019). A capability theory of the firm: An economics and (Strategic) management perspective. New Zealand Economic Papers, 53(1), 1-43. https://doi.org/10.1080/00779954.2017.1371208

Teece, D., Peteraf, M., \& Leih, S. (2016). Dynamic capabilities and organizational agility: Risk, uncertainty, and strategy in the innovation economy. California Management Review, 58(4), 13-35. https://doi.org/10.1525/cmr.2016.58.4.13

Teece, D. J., Pisano, G., \& Shuen, A. (1997). Dynamic capabilities and strategic management. Strategic Management Journal, 18(7), 509-533. https://doi.org/10.1002/(SICI)1097-0266(199708)18:7<509::AID-SMJ882>3.0.CO;2-Z

Terawatanavong, C., Whitwell, G. J., Widing, R. E., \& O'Cass, A. (2011). Technological turbulence, supplier market orientation, and buyer satisfaction. Journal of Business Research, 64(8), 911-918. https://doi.org/10.1016/j.jbusres.2010.09.003

Tikkanen, J. (2014). Dynamic capability influence on strategic agility: A case study in energy conservation industry. Unpublished Master`s Project. University of Oulu.

Tse, Y. K., Zhang, M., Akhtar, P., \& MacBryde, J. (2016). Embracing supply chain agility: An investigation in the electronics industry. Supply Chain Management: An International Journal, 21(1), 140-156. https://doi.org/10.1108/SCM-06-2015-0237

Turulja, L., \& Bajgorić, N. (2015). Information technology capability and its impact on firms' performance. SSRN Electronic Journal. https://doi.org/10.2139/ssrn.3280270

Voss, M., \& Kock, A. (2013). Impact of relationship value on project portfolio success - investigating the moderating effects of portfolio characteristics and external turbulence. International Journal of Project Management, 31(6), 847-861. https://doi.org/10.1016/j.ijproman.2012.11.005

Wang, C. L., \& Ahmed, P. K. (2007). Dynamic capabilities: A review and research agenda. International Journal of Management Reviews, 9(1), 31-51. https://doi.org/10.1111/j.1468-2370.2007.00201.x

Wang, Y., \& Feng, H. (2012). Customer relationship management capabilities Measurement, antecedents and consequences. Management Decision, 50, 115-129. https://doi.org/10.1108/00251741211194903

Winter, S. G. (2003). Understanding dynamic capabilities. Strategic Management Journal, 24, 991-996. https://doi.org/10.1002/smj.318

Yauch, C. A. (2010). Measuring agility as performance outcome. Journal of Manufacturing Technology Management, 22(3), 384-404. https://doi.org/10.1108/17410381111112738

Zaridis, A. D., \& Mousiolis, D. T. (2014). Entrepreneurship and SME's organisational structure: Elements of a successful business. Procedia-Social and Behavioral Sciences, 148, 463-467. https://doi.org/10.1016/j.sbspro.2014.07.066

\section{Copyrights}

Copyright for this article is retained by the author(s), with first publication rights granted to the journal.

This is an open-access article distributed under the terms and conditions of the Creative Commons Attribution license (http://creativecommons.org/licenses/by/4.0/). 